\title{
Huma Betang Philosophy as the Solidarity Prototype and Ethnic Conflict Prevention in Dayak Communities of Central Kalimantan
}

\author{
Eli Karliani*, Eddy Lion, Sakman Sakman \\ Department of Civic Education \\ Palangka Raya University \\ Palangka Raya, Indonesia \\ *eli.karliani@fkip.upr.ac.id
}

\begin{abstract}
This study aims analyzing the philosophy of huma betang as a solidarity prototype and the ethnic conflict prevention in the Dayak communities of Central Kalimantan. The ethnic conflict that occurred between Dayak and Madura ethnic in 2001 has caused trauma, so there is a need to prevent the conflict from recurring. This research was used depth interviews to some ethnic figures of Dayak people, Bali, Banjar, Java, Sulawesi, and Papua to discover the causes of conflict ethnic among Dayak and Madura; observation and document to analysis philosophy "Huma Betang". The research data are processed based on descriptive qualitative techniques. The results obtained: 1). Factors causing ethnic conflict of Dayak and Madura include: a). failure of ethnic coaching, territorial domination (politics); b). justice in legal process (law); c). tenacity in work (economy); d). differences in character and intercultural communication (social and culture); 2) the values of huma betang as symbol of solidarity and ethnic conflict prevention need to be understood, internalized, and implemented in community life because it contains value: be grateful for plurality, kinship, togetherness, solidarity, respect for individual rights (private/public).
\end{abstract}

Keywords - huma betang philosophy; ethnic conflict preventio; solidarity prototype

\section{INTRODUCTION}

The Dayak ethnic in Central Kalimantan Province witnessed a dark history related to the conflict outbreak in 2000 which reached its peak in 2001. The conflict spread to several regencies and Palangka Raya City. Many lives were taken both of the Madura ethnic and the Dayak as the indigenous ethnic. Hundreds of houses of Madura people were burned down to the ground when the conflict arose. This caused deep trauma for the parties involved [1-3]

To prevent ethnic conflicts to recur, various efforts from the government coordinated with local communities are necessary. One of the efforts should be made is to facilitate the bridging of communication and harmonious inter-cultural interactions so that the attitude of understanding, respect and coordination are built to reach the goal of living together peacefully. In an interethnic communication and interaction, the understanding of the philosophy of the indigenous tribe is necessary so that the ethnic migrants can adapt in their new residence without having conflicts $[4,5]$.

Ethnic conflicts generally occur when justice is not felt by one of the ethnic groups involved. Justice is related with the fulfillment of individual rights according to their portion of rights. Justice can be seen from many sectors, for instance in economy, politics, government, education, and social culture [5-8].

In Dayak culture the obedience to traditional customs is mirrored in the tribe's everyday life consisting relationships with God, human and nature. In interacting with other ethnicities, the Dayak communities generally have an accepting attitude, not discriminating against cultural backgrounds, religions, and customs. The Dayak community members live side by side with other ethnicities with different religious, cultural, custom and language backgrounds. This can be seen from Huma Betang philosophy as the Dayak life philosophy in making relations with other various tribes. Huma Betang is the prototype of the house model to live in by families from various religions, cultures and customs [4-7,9].

The Dayaks have lived their lives side by side with other tribes and nationalities since their ancestors' era. They have the attitude of openness, sincerity, and hospitability in virtue with Betang culture. They are famous as helpful to people (bajentabajorah), able to socialize with anybody from any ethnicities. This is in accordance with Huma Betang which is lived by many people from different religions, customs and cultures and they maintain living lives peacefully, harmoniously and without conflicts. In its essence, Betang culture reflects how diverse the attitude between individuals, groups, families, tribes can be, but it maintains the spirit of life of togetherness with mutual respect as the key of living life of peace and harmony $[6,7,9]$.

This research aims to analyze the philosophy of Huma Betang as the solidarity prototype and ethnic conflict prevention to the Dayak community of Central Kalimantan Province. Huma Betang philosophy contains values of the Dayak tribe of Central Kalimantan necessary to be understood by all ethnic groups. The values then need to be internalized in building intercultural relationships to create a peaceful and tranquil living on Dayak land. 


\section{METHOD}

This research employed in-depth interviews to discover the causes of conflict among Dayak and Madura people; observation and document analysis to discover the philosophy of "Huma Betang". The subjects of the research are some ethnic figures from Dayak ethnic, Bali, Banjar, Java, Sulawesi, and Papua. The research data were analyzed based on the procedural steps of the descriptive qualitative design which comprise reduction, display, conclusion and verification according to [10].

\section{RESUlt AND DisCUSSION}

\section{A. The Igniting Factors of the Ethnic Conflict between the Dayaknese and Madurese Tribes in Central Kalimantan Province}

Based on the interview results with Informant 1 (ethnic Balinese figure), it was testified that: "We can live safely and peacefully, as long as we learn from experience of the 2001 conflict. That year was an accumulation from previous heartbreaking events felt by the Dayaks. It was not just the Dayaks who felt heart broken, it applied to the non Dayak too. I myself had experience when the Madura men took jackfruits and coconuts just as they liked in Bukit Hindu, that was their character. Most of them have low education, and many of them are illiterate. Other ethnic migrants bring their skills. If they are transmigrating, they are ready to be farmers. Whereas many Madura people are seen unclear to what they do for a living. Another undesirable character of the Madura is that for example at the harbor, they put a price on things as they like." A similar story was reported by Informant 2 (ethnic Bataknese public figure), "almost all others of any tribes admitted that the Madurese are difficult to compromise with. They admit that they are stupid but they use their stupidity to impose their wills to others."

Generally, the Dayak community views the ethnic conflict of 2001 involving the Dayak and Madurese tribes as the peak point of a long process towards neglect of self esteem, culture, customs, dignity, and justice of the Madura people to the Dayak people. In relevance, Informant 3 (ethnic Dayak figure) reveals the following complaints: "We used to tolerate and be patient when a quarrel occurred with the Madurese people. Apparently they took advantages of our kindness and patience. They interpreted us as easy to be conquered and not brave. The Dayak people usually avoid conflicts and because they are felt pressed by migrants, eventually they step back far into the inland. This has hindered many members of the Dayak community from various types of advancement. The Madura people illustrate that the Dayak people are stupid and uncultured. The Madura people also have the habit of living together among their own tribe. This makes them form their own villages in the Dayak land. Thus, the 2001 conflict was a peak of defence towards the dignity of the Dayak ethnic, and our resistance towards tyranny and harrassment to the culture and customs we uphold as our way of life, especially the Huma Betang philosophy. The truth is that the 2001 conflict was also a protest to the security forces who could not uphold the values of justice in each of inter-ethnic quarrel solution, especially between the Dayak and Madura people."
Other than the descriptions mentioned above, it is seen from the document report of the deliberation results of the people of Palangaka Raya on 25-27 April 2001. The conflict was also triggered by the lack of sympathy of the Dayak people and other ethnic groups towards the Madura ethnic. The Madura people were considered unable to adapt, thieves, robbers, selfish, and to always be imposing their wills to others. In relations in inter-ethnic groups, the lack of sympathy to the Madura people felt by other ethnic groups is caused by the following factors:

- When living side by side: The Madura people are perceived insincere, dishonest, and disrespectful.

- They are unable to respect the culture of the community of Central Kalimantan.

- They commit crime or actions against the law.

- They solve quarrels with terror, violence, sharp weapons, firearms, and explosives.

- They protect their own kind who has violated the law.

- They take in new Madura migrants who have unclear identitities.

- They increase wages or fees beyond agreement.

- They ask for compensation for land or business land they rented.

- They get angry if what they sell is bargained or not bought. This is generally done by vegetable or grocery vendors.

- They like to threaten.

- Many of them are involved in crime and violence.

- When a quarrel occurs, they conduct gang beatings.

- They stab people from the back. They do not act like gentlemen.

- They bring the sharp weapon celurit (Madurese traditional machete) in public.

As it was revealed in the Red Book: Sampit's Etnic Conflict, People's Agreement of Aspirations Chronology, Analysis, Suggestions, Deliberation Foundation of the Dayak Society and Central Kalimantan (LMMDD-KT) [11], some factors ignite the conflict between the Dayak-Madura ethnics are:

- That the processes of marginalization and actions towards destitution in Central Kalimantan, seen from injustice of natural resources utilization and regional development and injustice towards the protection of living rights in society as well as the unability of the ethnic Madura to give tolerance towards almost all aspects of life of the Dayak ethnic in Central Kalimantan.

- Arrogance culture of the Madura ethnic that disparages the Dayak culture causes frictions entirely and 
completely unresolved both by the people involved and the goverment. The accumulated frictions cause quarrels and enlarged, peaked mass fighting from time to time.

- The tendency of the Madura people to take in their acquintances, family, relatives, and members of their tribe who lack education or without prior selections to Central Kalimantan, has made the province to accept them. Many of them conduct crimes and non tolerable manners to almost all aspects of life in the Dayak ethnic community living.

- These are the great loss for the Dayak ethnic, both for the morale and material. There is a blasphemy that the Dayak ethnic members are uncivilized, intolerant, inhumane and so on, which is quoted by individuals, mass media, and electronic media widespread, without considering the long life suffering of the Dayak community caused by the existance of Madura people in the province.

- The tendency of the Madura ethnic members to protect their own community members who commit offenses and crimes to the Dayaks has formed the accumulation of hatred which is a common social problem among non Madura communities in Central Kalimantan. IKAMA is an organization to save Madura ethnic members who commit crimes to non Madura community members.

- There is an effort from Madure ethnic figures to push the image that the ethnic conflict in Central Kalimantan was ignited by the Dayak ethnic's side, by referring only to the impacts of the conflict, without observing the roots and prior processes to the conflict.

- It is also seen from the effort of the Madura ethnic figures' provocation that the ethnic conflict in Sampit City was an ethnic cleansing towards the Muslims.

- There was a naive consideration from the Madura ethnic figures by delivering threats to the government officials of Central Kalimantan to impose their wills in solving the 2001 conflict. This act was done without considering that the communities in Central Kalimantan were victims of neglect of the Madura ethnic figures in educating their tribe members of making a living in Central Kalimantan.

- The Dayak tribe is very tolerant to the Madura people. Some Dayak families have accepted their children to marry members of the Madurese.

Some notes regarding the chain of conflict events involving both the ethnic Madura and Dayak are revealed (from Red Book: Sampit's Etnic Conflict, People's Agreement of Aspirations Chronology, Analysis, Suggestions, Deliberation Foundation of the Dayak Society and Central Kalimantan (LMMDD-KT). The chain of events recorded since 1982-2001 are [11]:
- In 1972 in Palangka Raya, a Dayak girl was raped by a Madura man. A reconciliation was made according to customary law.

- In 1982, a Dayak man was murdered by a Madura man. There was no investigation or solution based on law, the murderer was nowhere to be found.

- In 1983, in Bukit Batu District, Kasongan, a Kasongan community member of Dayak ethnic with Kaharingan religion named Pulai was killed. It was a gang beating between 1 (one) Dayak man and 30 (thirty) Madura people. Peace settlement was signed by both the Madura and Dayak ethnic figures. The settlement contains an agreement that if the Madura people repeat their crime, they will be ready to be banished out of Central Kalimantan.

- In 1996, in Palangka Raya, a Dayak girl was raped inside the Panala cinema and killed ruthlessly by a Madura man. The punishment for it was perceived far from severe.

- In 1997, in Karang Langit village, South Barito, 2 (two) Dayak men were involved in a gang fight of 40 (forty) Madura men. However, all of the Madura people involved were found dead. The two Dayak men used martial arts as their self-defense. The punishment for the two Dayak men was severe.

- In 1997, in Tumbang Samba, the capital of the district Central Katingan, a boy named Waldi was killed by a Madura man, a satay vendor. The young boy was killed with 30 (thirty) stab wounds. He did not know anything about the quarrel, he was just passing by. The satay vendor could not catch the man he was in the quarrel with who ran away and Waldi was purely innocent.

- In 1998, in Palangka Raya, a Dayak man was in a gang fight with 4 (four) Madura men. The Dayak man was found dead while the Madura men involved escaped. There was no settelement or solution based on law.

- In1999, in Palangka Raya, a staff of public orderliness was stabbed by a Madura man. The Madura man was arrested and detained in Palangka Raya Police Department. The next day a group of Madura men came to the police station and demanded their friend to be released without charges. The Madura was released without charges.

- In 1999, in Palangka Raya, 2 (two) Dayak men were attacked by several Madura men related to a case of land dispute. The two Dayak men were found dead and the Madura men involved had escaped. A Javanese man, served as a witness to the crime was sentenced 1,5 years in prison for false testimony.

- In 1999, in Pangkut, the capital of the district North Arut, West Kotawaringin Regency, a mass fighting occurred between the Dayak and Madura ethnic members. The Madura people involved tried to rob the gold the Dayak people was mining. Many Dayak 
victims found dead and the impacts of the dispute remained unsettled.

- In 1999, in Tumbang Samba, a couple of husband (Iba) and wife were stabbed by 3 (three) Madura men; the couple suffered severe injuries and were treated at the General Hospital Dr. Doris Sylvanus Palangka Raya. The costs for surgeries and treatments were settled by the Regional Department of Central Kalimantan. The Madura offenders were not arrested, they even escaped to Madura. It was told that 3 (three) Madurese men came to Iba's family house and asked for water because they were thirsty. When Iba was giving them water, they stabbed him. His wife tried to defend him but she got stabbed, too. It was told that the Madura people came for revenge but they came to the wrong house.

- In 2000, in Pangkut, West Kotawaringin, 1 (one) Dayak family was slaughtered to death by Madura people. The offender ran away. The case remained unsettled.

- In 2000, in Palangka Raya, 1 (one) Dayak man was killed by a Madura gang in front of Imanuel church at Bangka Street. The offenders ran away. No law settlements.

- In 2000, in Kereng Pangi, Kasongan, East Kotawaringin Regency, a murder happened to Sendung (child name). The death was caused by gang beatings of the Madura ethnic. The offenders escaped to Madura island. There were no processes of law. The authority could not solve the crime committed entirely.

- In 2001, in Sampit, between 17-20 February, many Dayak community members were killed. The Madura ethnic initiated the attack.

- In 2001, in Palangka Raya, on 25 February, a Dayak man was killed by a Madura man. Many other Conflicts also occured between the Madura people with the people of West Kalimantan, East Kalimantan, and South Kalimantan provinces.

Talking about conflicts, as described by Informant 4 (education and anthropology expert of Palangka Raya University, the public figure who initiated the formation of Cross Ethnic Communication Forum of Central Kalimantan): Every body eventually learns from the conflict, not negatively but positively. It means that there is a benefit from the conflict. For example, a husband and a wife who have a conflict will reveal the problems igniting the conflict. Positively, in an interethnic groups, people can live life more harmoniously learning from the conflict. Actually, there is more positivity of the conflict. The Dayak tribe can reflect and introspect and make changes for the better in their surroundings, the Madurese tribe will change their stubborn attitude. A cultural transformation will definitely happen both for the Madura and Dayak ethnics.

Similar notes were also stated by Informant 5 (Government Official of Nation and Politics Union): "With the ethnic conflict of 2001 the Madurese people have realized and asked for forgiveness to the Dayak ethnic community, they regret it deeply. At a forgiveness event, government officials of Central
Kalimantan who came were hugged and asked for forgiveness. "Forgive us, Sirs." In Dayak language they said, "ije kami mulik, Pak" "let us go home." "The Dayak ethnic community members consider the 2001 conflict as a big catastrophe due to cosmos imbalances, especially regarding the rifts in human relations. In the past, the Madura ethnic might have thought that the Dayak people were cowards, because we have similar characteristics with the Javanese people. In Java, there is a culture of "harmony" where in Dayak culture we have the culture of "tolerance" in quotation marks, not because we are cowards. We were interpreted wrongly, because it seemed easy to conquer the Dayak. They chase us here and there, we run, not because we are afraid, we want to avoid conflicts. In essence, the philosophy taught by our ancestors, "we surrender ourselves to nature, to the power of God and to human kind' means that we maintain the balance of cosmos. However, as we know, patience has its limit. Our backs were against the wall, there was no space left to step back anymore, so we fought back," said Informant 5 .

From the result of an interview with Informant 6 (a Madura community member), it was stated that when the conflict took place, he was already in Palangka Raya, ready to be a vendor. As a consequence, he had to move to Tangerang and Banten. His belongings were left entrusted to his neighbor, but the neighbor disappeared. "I did not know the issues led to the conflict. I was here to be a vendor. What I know is that when the conflict occured, all of the Madura people were sent away. I am not afraid to return to the Dayak land. The ones with the problems were those who were arrogant and could not adapt with the local people here. Madura has four regencies, Bangkalan, Pamekasan, Sampang and Sumenep. Each regency has its own charachteristics. Some people are stubborn than the others that some of us who are innocent get blamed as well.

Based on the explanations regarding the igniting causes led to the conflict above, it is understood that in general the root cause is the inter-cultural communication problem. Although there are other factors such as economy, politics, law, and social culture. In economy, the Dayak people are basically too spoiled by the wealth of nature and there is a tendency of being picky with jobs. While the Madura people are more tenacious in all kinds of jobs. In politics, the 2001 ethnic conflict was more caused by the failure of Madura ethnic figures in educating their community to adapt with the local culture. There is an intention of the Madura ethnic to dominate the Sampit region as their second Sampang which causes all the Dayak people to unite and fight the ill intention by evicting all the Madura people from the Dayak's land in Central Kalimantan. Then the conflict spread to Palangka Raya and other neighboring regencies. Many Madura people borrow land from the Dayak community, but when they are asked to return the land they borrow, they ask for money compensation, some even have already changed the ownership letters of the borrowed land as theirs. In the cases of law, it seems that many nbn domination tendency is seen from one ethnic group to the other. From the 2001 conflict where culture differences were iniatially a hindrance impacts the stereotype of the Madura ethnic to the Dayak ethnic who tend not to fight back. The conflict originator in Sampit of Central Kalimantan Province is that many sources declare Sampit as the second Sampang 
cannot be accepted by the indigenous tribe. Territorial domination has been seen as one of the factors leading to the 2001 conflict $[1,2,6-8]$.

\section{B. Huma Betang Philosophy as the Solidarity Prototype and Ethnic Conflict Prevention}

It is cultivated in Betang culture which organizing the lives of its inhabitants with values such as law and order, tolerance, rules and mutual cooperation. Besides, it is also taught how to maintain and respect individual as well as common rights of each of the inhabitants. If we look at the history of Huma Betang there are many aspects originating the existance of the traditional Dayak house. It is not only a place to live, it has aims and objectives. Those are the foregrounds of the Huma Betang existance. Huma Betang can be stated as the typical traditional house of the Dayak tribe especially the Dayak of Central Kalimantan. Furthermore, Huma Betang is the roof for dozens even hundreds of households living with partitions to separate one family to another. Nevertheless, the life inside the house is safe, peaceful and tranquil despite the differences among its members. This is the outline of Huma Betang, uniquely, it is not only about what it is but also when observed it will be found elements closely related to the values inside of it $[6,12,7,8]$.

Through its etymology, huma literally means house and betang literally means long/big. Huma Betang means a long house or a big house. The construction of its building enables it to contain 100-200 family members or 10-40 households. Huma Betang is also recognized as a tribe house consisting one big family led by a tribe chief (bakas lewu) live inside of it. Huma Betang is built in big size with approximately 30-150 meters in length, 10-30 meters in width, with pillars 3-4 meter height from land surface. The pillars supporting the house are made by ulin wood or tabalien $[13,14,7,8]$.

To understand the values inside Huma Betang, it is necessary to understand the meaning of philosophy itself. Philosophy is the truth that is considered true. This section will discuss the philosophy of Huma Betang and its cultural values. Huma Betang of Central Kalimantan upholds the values of peace, anti-violence and high tolerance of different religions. More specifically, the values contained in Huma Betang encompass four pillars: togetherness, honesty, equality and mutual respect (tolerance). The descriptions to the four pillars are:

- The value of togetherness is the attitude of mutual cooperation. For example, the cooperation in maintaining Huma Betang and working in the rice field.

- The value of honesty carries the meaning of no lying, either a small or big lie. For example, if someone asks you your name, then you have to answer it honestly.

- The value of equality is the attitude of compatibility and equality where everyone living in the Betang house has the same rights and obligations.

- The value of tolerance is the attitude of respect towards the differences or different backgrounds of others. For example, being respectful to each other in the house despite religion differences $[1,2,6-8]$.

The traditional customary values of Huma Betang are seen in belum bahadat (well-mannered living) and in the spirit of isen mulang(perseverance/steadfastness). Belum bahadat in the everyday life of the community in Central Kalimantan teaches that everyone must apply "Belum Bahadat" which means that they must live a well-mannered living. The conditions of Belum Bahadat apply to all people, taught from childhood and adolescence or puberty. Belum Bahadat is also demanded to the adults, the rich, the poor, the commoners, as well as to those with prestigious positions in society. The roles of traditional customs in society are:

- The traditional customs teach that it is obligatory for children to respect their parents, grandparents, uncles and aunts, and the young must respect the old. In Dayak community, children are taught how to behave and say polite words as a sign of respect to the old. One of the polite language forms is that the young is not allowed to call the old by their names but with terms in family tree.

- The traditional customs teach everyone to respect those who are married and have children. It is more respectful to call them with their children's names preceded by terms in the family tree, even if they are younger or their level in family tree is lower.

- The traditional customs teach that the male and female must respect each other. The philosophy of Central Kalimantan community places human on a very noble position. It is proven in "Tandak Batang Garing" of a Dayaknese Sangen language which refer men as "Habatang Garing, Habaner Garantung, Habasung Runjan," and female as "Balimut Bulau Pasihai Runjan, Habungking Bakam Batu, Nahasak Nyalung Kaharingan Belum." The men must respect, protect, and maintain the dignity of women and his family. Words, attitudes and actions that harras a girl or a woman can be sued according to customary law.

- The traditional customs teach the manners of visiting and welcoming guests, they are:

- When an adult male intends to meet the host, while the host is not available at home but his wife, he should refrain and not need to enter the house. Message delivery or conversations between the male guest and the host's wife is adequate to be done at the front yard of the house. The wife need not to invite the male guest inside, considering that her husband is not at home. This is to illustrate that the guest is respectful to the dignity of the host and the host's wife is respectful to the dignity of her husband. If a husband intends to meet a girl or a married woman, he should ask his wife to come along.

- If a young man intends to meet his girlfriend, while apparently she is alone, the man should refrain and the girlfriend should not invite her boyfriend to enter the house to avoid gossips. It is 
impolite for a girl without a company at home to accept a male guest who is not a close relative. A girl who is without a company or urgency should also not come to visit a man who is not her close relative. Therefore, the girl should keep her own, her parents' and her family's dignity.

Huma Betang philosophy is a long house where families with different religious, language, ethnic backgrounds live together harmoniously. Betang culture is a system of values or living norms in society based on familial relationships, togetherness, equality in civil society. Traditions and adaptations that have been developed in the last one century since the Tumbang Anoi 1894 Peace Meeting, contain: 1) Peace values (against violent solutions), emphasizing the values of hapakat-basara 'agreements through deliberation' in solving problems; 2) Belief in the one true God (freedom of religion); 3) Justice in humanity; 4) Nationalism; 5) Togetherness in prosperity for justice. This value system will flourish towards a new civilization in Indonesia and regions of Central Kalimantan. Harmony and equality in diversity and plurality of a civil society, prosperous society, and Bhinneka Tunggal Ika society, are coherent with the Dayak tribe characteristics. Harsh polarization and domination from one another will never guarantee peace in the earth of Kalimantan [1,2,6-8].

The living in togetherness atmosphere of the Dayak ethnic with all other ethnics and nationalities as seen in the document of Dayak Ngaju custom values has been indeed implemented since their ancestor's time. The Dayaks have the characters of openness, sincerity, and hospitability in accordance with Betang culture. The Dayaks are famous of their helpfulness to others (bajenta-bajorah), can socialize with anybody, from any ethnicities. It is relevant with Betang culture as a house inhabited harmoniously and peacefully by many people with different religion, custom and culture backgrounds. The truth of Betang culture is that with vast diversity of individual, group, family and tribe characters, the spirit of togetherness and mutual respect as the key to peaceful and tranquil life is sustained. The noble values of Betang culture show that the Dayak tribe has lived their lives in the spirit of Pancasila. The elements of Pancasila are entirely contained in the values of living of the Dayaks in Betang culture [1,2,6-8].

\section{CONCLUSION}

Ethnic conflicts are much influenced by inter-ethnic stereotypes. Bad presumptions become the elements of the igniting factors. Low quality of inter-cultural communication is also one of the ignitions to the conflict. Bad presumptions to a certain ethnic group will influence a person in his/her interactions. Without communication relations and frequent interactions between inter-ethnic groups, bad presumptions will continue to grow and form an antipathy from an ethnic group to the other. The living pattern of the Madurese tribe who segeregate themselves in their own ethnic group and seldom interact with their surroundings cause them lack of understanding and tolerance to other characters and cultures. Unlike some other ethnic groups that have strategically adapted and assimilated themselves in the Dayak culture. The factors causing ethnic conflict of Dayak and Madura includefailure of ethnic coaching, territorial domination (politics); justice in legal process (law); tenacity in work (economy); differences in character and intercultural communication (social and culture).

"Huma Betang" philosophy values adhere in each Dayak person of the Central Kalimantan Province. The values are not only cultural heritage from Dayak ancestors but also are sustained by the community of Central Kalimantan. "Huma Betang" philosophy contains at familial relationships, togetherness, equality in civil society of Bhinneka Tunggal Ika (Unity in Diversity) as the Pancasila sub-culture. The values of huma betang as symbol of solidarity and ethnic conflict prevention need to be understood, internalized, and implemented in community life because it contains value: be grateful for plurality, kinship, togetherness, solidarity, respect for individual rights (private/public).

\section{ACKNOWLEDGEMENTS}

The researcher thanked the Dean of Faculty Teaching and Education who has provided material support.

\section{REFERENCES}

[1] Ruslikan, "Konflik Dayak Madura di Kalimantan Tengah: Melacak Akar Masalah dan Tawaran Solusi," Jurnal Masyarakat, Kebudayaan dan Politik, vol. 14, no. 4, pp. 1-12, Oktober 2001.

[2] E. Karliani, "Pembinaan Masyarakat Multikultural Dalam Meningkatkan Integrasi Bangsa (Studi Kasus Hubungan antar Etnik di Kota Palangka Raya)," UNM: Jurnal Pendidikan Pancasila dan Kewarganegaraan. Vol. 24 no. 2, Agustus 2011

[3] C. Juditha, "Stereotip dan Prasangka dalam Konflik Etnis Tionghoa dan Bugis Makassar," Jurnal Ilmu Komunikasi, vol.12, no.1 Juni 2015, pp. 87-104, 2015

[4] M. Chingono, "The quest for happiness as an underlying motive for violent conflict in Africa," African Journal on Conflict Resolution, vol.17, no. 2, 2017.

[5] H. Jaghoory, K. Björkqvist, and K. Österman, "Self-reported Peacefu Conflict Resolution Behaviour in Iranian and Finnish Adolescents" European Journal of Social Sciences Education and Research Jan. vol. 12, no. 1, April 2018.

[6] M. Alyokhina, Mardieva, Shcuklina "The Ethnic Stereotype of Tatars in Russian Linguistic Culture," Journal of Organizational Culture, Communications and Conflict, vol. 20, Special Issue, 2016.

[7] V. Ramilevna, "Cultural Learning Students' Perspectives," Journal of Organizational Culture, Communications and Conflict, volume 20, Special Issue, 2016.

[8] A. Malizia, Deborah and K. J. Jameson, "Hidden in plain view: The impact of mediation on the mediator and implications for conflict resolution Education," Wiley : Association for conflict Resolution, 2017.

[9] R. Frendika, E.T. Sule, and M. Kusman, "Personal Value Versus Cultural Competency Towards Self-Confidence Through Personal Branding Of Employees Between Expatriates And Local Employees," Journal of Organizational Culture, Communications and Conflict, vol. 22, no. 1, pp. 1-7, 2018.

[10] B. Miles, Matthew and A.M. Huberman, Analisis Data Kualitatif : Buku Sumber Tentang Metode-Metode Baru, UI Press : Jakarta, 2007.

[11] Presidium LMMDD-KT, Konflik Etnik Sampit: Kronologi,Kesepakatan Aspirasi Masyarakat, Analisis, dan Saran, Palangkaraya: LMMDD-KT, 2001.

[12] S. Tremaria, "Violent Caracas: Understanding Violence and Homicide in Contemporary Venezuela," IJCV, vol. 10, no 1, 2016. 
[13] S.A. Rusan, Sejarah Kalimantan Tenga, Palangka Raya: Lembaga Penelitian Unpar.
[14] H.M. Abubakar, "Huma Betang Dan Aktualisasi Nilai Kearifan Lokal Dalam Budaya Dayak,” Jurnal Humanika, vol. 1, no. 2, Juli 2016. 